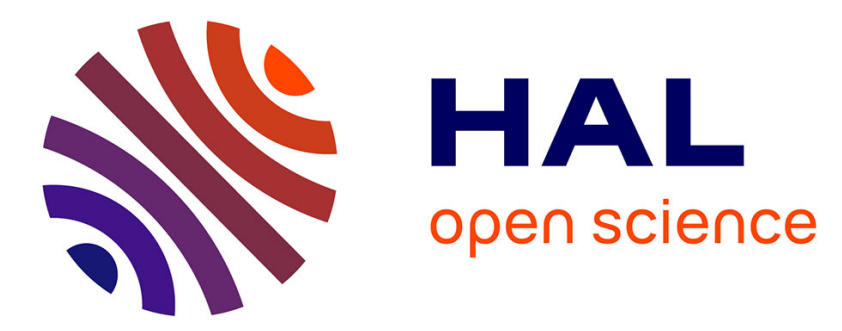

\title{
Light transmissivity of tube shelters affects root growth and biomass allocation of Quercus ilex L. and Pinus halepensis Mill
}

Alberto Vázquez de Castro, Juan A. Oliet, Jaime Puértolas, Douglass F. Jacobs

\section{To cite this version:}

Alberto Vázquez de Castro, Juan A. Oliet, Jaime Puértolas, Douglass F. Jacobs. Light transmissivity of tube shelters affects root growth and biomass allocation of Quercus ilex L. and Pinus halepensis Mill. Annals of Forest Science, 2014, 71 (1), pp.91-99. 10.1007/s13595-013-0335-3 . hal-01098389

\section{HAL Id: hal-01098389 \\ https://hal.science/hal-01098389}

Submitted on 24 Dec 2014

HAL is a multi-disciplinary open access archive for the deposit and dissemination of scientific research documents, whether they are published or not. The documents may come from teaching and research institutions in France or abroad, or from public or private research centers.
L'archive ouverte pluridisciplinaire HAL, est destinée au dépôt et à la diffusion de documents scientifiques de niveau recherche, publiés ou non, émanant des établissements d'enseignement et de recherche français ou étrangers, des laboratoires publics ou privés. 


\title{
Light transmissivity of tube shelters affects root growth and biomass allocation of Quercus ilex L. and Pinus halepensis Mill
}

\author{
Alberto Vázquez de Castro • Juan A. Oliet • \\ Jaime Puértolas • Douglass F. Jacobs
}

Received: 7 June 2013 / Accepted: 1 October 2013 /Published online: 25 October 2013

(C) INRA and Springer-Verlag France 2013

\begin{abstract}
- Context Tube shelters have been shown to enhance field performance of several Mediterranean species, but responses of newly planted seedlings to the microenvironment induced by shelter walls with different light transmissivity are still poorly documented.

- Aims We studied effects of a range of shelters with varying light transmissivity on post-planting seedling responses during the wet season establishment phase for two Mediterranean trees of contrasting functional ecology.

- Methods Root growth, biomass allocation, water potential, and chlorophyll fluorescence of Quercus ilex and Pinus
\end{abstract}

\section{Handling Editor: Erwin Dreyer}

Contribution of the co-authors Alberto Vázquez De Castro took most of the measurements, performed data analysis, and wrote most of the paper.

Juan A. Oliet supervised and coordinated research project, designed and installed the experiment, took some measurements, and contributed to writing the paper and running data analysis.

Jaime Puértolas took fluorescence measurements and contributed to the experimental design and to writing the paper, as well as to data analysis. Douglass F. Jacobs contributed to the experimental design and installing the experiment, as well as to writing the paper.

A. V. de Castro · J. A. Oliet $(\bowtie)$

Departamento de Silvopascicultura, Escuela Técnica Superior de Ingenieros de Montes, Universidad Politécnica de Madrid, Ciudad Universitaria s/n, 24040 Madrid, Spain

e-mail: juan.oliet@upm.es

J. Puértolas

Lancaster Environment Centre, Lancaster University, Lancaster LA1 4YQ, UK

\section{F. Jacobs}

Department of Forestry and Natural Resources, Hardwood Tree Improvement and Regeneration Center, Purdue University, 715 West State Street, West Lafayette, IN 47907, USA halepensis seedlings were evaluated across shelters varying in light transmissivity $(80,40,20$, and $10 \%$ plus a mesh shelter) with irrigation.

- Results Plants in dark tubes (20 and $10 \%$ light transmissivity) had less above- and belowground growth and more than two times greater leaf to protruding roots mass ratio, with shoot growth response of $Q$. ilex being less plastic. Ratio of leaf area/protruding roots area decreased when light transmissivity increased, although no differences were found at $\geq 40 \%$ transmissivity. Xylem water potential indicated lack of water stress, and high maximum photosynthetic efficiency $\left(F_{\mathrm{v}} / F_{\mathrm{m}}\right)$ values show no photoinhibition symptoms irrespective of light transmissivity.

- Conclusion Shelter transmissivity $\geq 40 \%$ promotes rapid and vigorous root growth immediately after planting for these species. This minimum transmissivity should be considered as a target when designing shelters to help root development and improve water balance of Mediterranean seedlings.

Keywords Forest restoration - Mediterranean climate . Treeshelters $\cdot$ Transplanting performance $\cdot$ Light ambient response $\cdot$ Aleppo pine $\cdot$ Holm oak $\cdot$ Chlorophyll fluorescence

\section{Introduction}

In Mediterranean ecosystems, forest restoration is often compromised by low and unpredictable rainfall, high temperatures, excessive radiation (Pausas et al. 2004), and predation by ungulates and rodents (Savill et al. 1997). Under these disturbed environments, the seedling establishment phase is a primary constraint for the continuity of plant populations (Lloret et al. 1999). The current scenario of climate change, with higher probabilities of extreme, harsh summers, suggests that the success of restoration programs in dry Mediterranean 
environments will require improvements in planting techniques (Valladares et al. 2004; Oliet and Jacobs 2012).

In this sense, one of the most widespread cultural practices in reforestation programs in Mediterranean climates over the past 20 years is the use of tube shelters (Oliet et al. 2005; del Campo et al. 2006). Along with protecting seedlings from animal predation in forest plantations, the shelter environment may reduce transpiration and net $\mathrm{CO}_{2}$ assimilation rates of plants (Dupraz and Bergez 1999) and alter patterns of biomass allocation (Sharpe et al. 1999; Sharew and Hairston-Strang 2005). This research, mostly carried out in temperate environments, has prompted the design of new tube shelters that are more efficient for plant growth (Bergez and Dupraz 2000, 2009). Previous studies under dry Mediterranean conditions, which are characterized by mild, wet springs and hot, dry summers, have found that both temperature and evaporative demand are higher inside compared to outside of tubes (Bellot et al. 2002; Oliet and Jacobs 2007; Close et al. 2009). Despite these unfavorable conditions, field results have demonstrated enhanced seedling survival in tube shelters (Navarro-Cerrillo et al. 2005; Oliet et al. 2005), and other experiments examining multiple species have found a species-specific response, with higher survival for sheltered seedlings of shade tolerant Mediterranean species (Oliet et al. 2003; Padilla et al. 2011). These results suggest a positive effect of tube shelters due to light reduction (Puértolas et al. 2010) and support the rationale of searching for an optimum shelter wall light transmissivity that minimizes potential negative impacts of excessive light availability. Under Mediterranean conditions, however, summer drought is the main threat for plantation success (Pausas et al. 2004; Villar-Salvador et al. 2012). Seedlings are commonly planted in autumn or winter when moisture is not limiting (Palacios et al. 2009) and roots grow until reaching deep soil layers. A deep root system allows plants to escape the desiccation of top soil layers during the subsequent dry season, thereby improving water uptake and increasing the probability of survival (Lloret et al. 1999). Thus, photosynthesis and biomass allocation to roots during the first months after planting is critical for survival under these conditions (Villar-Salvador et al. 2012). In this context, higher temperatures inside tube shelters (Bergez and Dupraz 2000; Oliet and Jacobs 2007) could increase photosynthetic rates and, consequently, root growth in winter and spring (Bellot et al. 2002; Pemán et al. 2010). However, light reduction of tube shelters may cause an opposite effect, depleting assimilation rates and, in turn, plant growth (Oliet and Jacobs 2007; Puértolas et al. 2010). In addition, shading is known to increase carbon allocation to shoots at the expense of root growth, reducing the water balance in a species-specific response pattern (Jiménez et al. 2005; Gómez-Aparicio et al. 2006; Puértolas et al. 2009). In summary, the role of shelters as a barrier to excessive radiation and as a promoter of root growth and water balance ratio implicates light transmissivity as a crucial parameter when designing shelters for Mediterranean species
(Puértolas et al. 2010). Furthermore, diversity of responses to light availability within Mediterranean forest species is large (Gómez-Aparicio et al. 2006), suggesting that species-specific influences of transmissivity on key plant traits are essential to determine the optimum shelter design for a given species. To our knowledge, however, very few studies have addressed the effect of light transmissivity of the shelter on plant performance of Mediterranean species (Dupraz 1997a).

Shelters are manufactured with a variety of design characteristics such as color, material, ventilation system, size, and light transmissivity, with strong corresponding effects on seedling physiological performance and planting response (Bergez and Dupraz 2000; Oliet et al. 2003; Sharew and HairstonStrang 2005). Although some studies have analyzed the response of seedlings to light transmissivity of commercial shelters in Mediterranean species (Oliet et al. 2003, 2007; Puértolas et al. 2010; Pemán et al. 2010), no experiment has tested the effect of a wide transmissivity gradient of shelters with uniform structural design. In Oliet et al. (2003), Quercus ilex L. survival after planting was reduced when light transmissivity of a commercial non-ventilated shelter decreased to $13 \%$, but this study compared different models of shelters, with varying red/far red ratios and none with light transmissivity over $60 \%$. Tree shelters are complex systems in which light availability interacts with other environmental variables, such as temperature and water stress, with feedback effects on plant physiology (Oliet and Jacobs 2007; Bergez and Dupraz 2009; Pemán et al. 2010). Thus, studies specifically designed to analyze seedling responses to light transmissivity of tree shelters are needed to identify levels that optimize plant response.

The aim of this experiment was to analyze the posttransplant effects of light transmissivity of tube shelters on morphology and physiology of two Mediterranean forest species (Q. ilex L. and Pinus halepensis Mill.) during early establishment. Two hypotheses were tested: (1) during the wet period, clear tubes will promote root growth and improve the water balance ratio, and (2) this effect depends on the light requirements of each species. To test these hypotheses, a planting experiment was carried out with the aforementioned species testing four tube shelters varying along a light transmissivity gradient, plus a mesh serving as an external control. Water potential and chlorophyll fluorescence measurements were also taken to understand the potential effects of differences in micro-environmental conditions generated by the transmissivity range. As a result, we propose a range of light transmissivity of shelter walls that is most appropriate for common forest species of the Mediterranean basin. The studied species are the most commonly used species in reforestation programs in Spain (MAPA 2006) and exhibit strong ecological differences according to their successional stage: the pioneer, shade-intolerant $P$. halepensis Mill. and the late successional, shade-tolerant $Q$. ilex L. (Pausas et al. 2004; Ninemets and Valladares 2006). 


\section{Material and methods}

\subsection{Plant material and experimental design}

Q. ilex L. subsp. ballota (Desf.) Samp. acorns from Extremadurense/Montes de Toledo provenance (ES-45-11c, Alía Miranda et al. 2009) were sown in $300 \mathrm{~cm}^{3}$ containers filled with fertilized peat moss and grown outdoors for 12 months; fertigation was applied during the growth phase. P. halepensis seeds from La Mancha provenance (ES-24-08, Alía Miranda et al. 2009) were sown in $200 \mathrm{~cm}^{3}$ containers filled with a mixture of peat moss, black peat, and a slowrelease fertilizer and grown outdoors for 12 months. The preplanting average height, diameter, and dry weight of shoots and roots of each species were, respectively (mean \pm standard error), $18.4 \pm 3.66 \mathrm{~cm}, 3.67 \pm 0.38 \mathrm{~mm}, 3.85 \pm 0.05 \mathrm{~g}$, and $1.88 \pm 0.04 \mathrm{~g}$ for pine and $18.1 \pm 5.91 \mathrm{~cm}, 3.47 \pm 0.60 \mathrm{~mm}, 3.50 \pm 0.16 \mathrm{~g}$, and $4.79 \pm 0.15 \mathrm{~g}$ for oak $(n=9)$.

Seedlings were planted during April 27 to May 5, 2009 in an experimental plot at the School of Forestry, Technological University of Madrid $\left(40^{\circ} 27^{\prime} \mathrm{N} ; 3^{\circ} 43^{\prime} \mathrm{W}, 664 \mathrm{~m}\right.$ a.s.l). The soil was a sandy loam (59\% sand, $21 \%$ silt, and $20 \%$ clay), with $\mathrm{pH}=7.56,0.89 \%$ of organic matter, $0.07 \%$ of total $\mathrm{N}, 2.34 \mathrm{ppm}$ of $\mathrm{P}$, and $59.8 \mathrm{ppm}$ of $\mathrm{K}$. The accumulated rainfall during the experiment was $135 \mathrm{~mm}$, while the average maximum, minimum, and mean temperatures were $25.7,11.5$, and $18.6{ }^{\circ} \mathrm{C}$, respectively (AEMET, Spanish Department of Agriculture and Environment). The study examined two factors: light transmissivity of tube shelter with five levels (four levels of tube shelter transmissivity, see below, plus a mesh) and the species factor with two levels ( $Q$. ilex and $P$. halepensis). Species were systematically distributed (i.e., pine and oak were alternately planted), whereas tube shelters were randomly arranged across species. Twelve plants per treatment combination (species and light transmissivity) were used. The tube shelters tested were made from plastic material supplied by Repsol Química (Spain). All tubes were composed of one base copolymer with additives added to attain different values of light transmissivity of visible light: $82.6 \%$ (T80), $38.7 \%$ (T40), $18.5 \%$ (T20), and $11.9 \%$ (T10), maintaining the red/far red ratio around 1 (neutral shade) in all tubes (values determined by Repsol). Tube shelters were circular, single-walled tubes, $60 \mathrm{~cm}$ tall $\times 10 \mathrm{~cm}$ wide, with four ventilation holes facing each other of $2.5 \mathrm{~cm}$ width and situated at 20 and $40 \mathrm{~cm}$ in height. Ventilation holes are provided in Mediterranean areas as a means to reduce overheating of the shelter in summer (Oliet et al. 2003). The mesh used as a control was a $60 \mathrm{~cm}$ tall $\times 15 \mathrm{~cm}$ wide cylindrical polyethylene net with mesh holes $0.8 \times 0.8 \mathrm{~cm}$. The light transmissivity of the mesh was determined in several daily cycles of photosynthetically active photon flux density measurements with three sensor replicates (SQ-212 ${ }^{\circledR}$, Apogee, USA). On average, mesh transmissivity was $83 \%$, but in contrast with tubes, mostly direct sunlight reached the interior of the shelter. Seedlings were transplanted into Root Control bags RCL12 ${ }^{\circledR}$ (Root Control, USA; $30 \mathrm{~cm}$ deep $\times 30 \mathrm{~cm}$ wide) filled with soil. In turn, the bags were placed in holes opened by a mechanical auger and covered with soil. This procedure allowed complete recovery of the root system during excavation at the end of the experiment. The Root Control bags promote root branching when tips reach the wall, preventing them from exiting the bag (Whitcomb 2005), but at the same time are permeable to water of the surrounding soil. The spacing of the planting was $1 \times 1 \mathrm{~m}$. To avoid water stress, a drip irrigation system was installed. Soil moisture was assessed monthly in half of the plants by Time Domain Reflectometry (HydroSense $^{\mathrm{TM}}$, SCA, Australia). Humidity between 12 and $20 \mathrm{~cm}$ soil depth was controlled by drip irrigation and never dropped below $23 \%$.

\subsection{Evaluation of microclimatic conditions inside shelters}

To assess the effect of light transmissivity of tube shelters on microclimate conditions inside shelters, air temperature and relative humidity $(\mathrm{RH})$ data logger sensors (U23-001 ${ }^{\circledR}$ Onset, USA) were installed in the shelters from 15 September to 1 October 2009. During these days, the average temperature was $27.2{ }^{\circ} \mathrm{C}$. Hobo probes were randomly installed inside two shelters of each type, at a height between both pairs of ventilation holes. Two additional probes were installed at the same height and shaded to record external air temperature and $\mathrm{RH}$. These variables were recorded every $10 \mathrm{~min}$. We selected data from sunny days within the interval for parameter calculation. Vapor pressure deficit (VPD) was calculated from temperature and RH data. Mean VPD and temperature from 0900 to 1900 hours and from 2000 to 0800 hours were calculated for the selected sunny days.

\subsection{Evaluation of water potential and chlorophyll fluorescence}

A small window was opened in the tube shelter to facilitate sampling for water potential measurements and fluorescence; the window was otherwise closed. Water potential was measured at midday in order to detect effects of variables such as VPD and radiation within each level of light availability on plant water status. Midday shoot water potential $\left(\Psi_{\mathrm{M}}\right)$ was measured once during two consecutive sunny days (12 and 13 August 2009) on four plants per species and shelter type (40 plants in total). A $2.5-6 \mathrm{~cm}$ length (pine) or 6 to 10 leaves (Q. ilex) twig of the upper third of the plant was excised. The sample was taken between 1230 and 1430 hours solar time, wrapped in aluminum foil inside a sealed bag and stored at $4{ }^{\circ} \mathrm{C}$ until measured for shoot xylem water potential within $2 \mathrm{~h}$ using a pressure chamber (Model $1000^{\circledR}$, PMS Instruments Company, USA).

Chlorophyll fluorescence measurements were conducted on four plants per species and type of shelter at two dates during the experiment (26 June and 5 August) using the same plants 
for both measurements. The measurements were made in a fully expanded leaf (oak) or bundle of needles (pine) of the upper third of the seedling. The ratio of variable to maximum fluorescence $\left(F_{\mathrm{v}} / F_{\mathrm{m}}\right)$ was measured at dawn and at noon with a pulse-modulated fluorometer $\left(\mathrm{FMS}^{\circledR}\right.$, Hansathech Instruments, UK). Prior to $F_{\mathrm{v}} / F_{\mathrm{m}}$ measurements, leaves were dark acclimated for $30 \mathrm{~min}$.

\subsection{Evaluation of biomass and morphological development}

Height and stem diameter were measured on every plant (12 plants per species and shelter treatment) twice, at the beginning (5 May 2009) and the end of the experiment (20 October 2009). Harvesting of plants for evaluation of biomass and morphology was performed on 10 November 2009. Five plants per species and shelter were randomly selected. Seedlings were excavated from pots, and each plant was separated into different parts: plug, roots protruding from the plug, leaves, and stem. Leaves were scanned and area measured with an image analyzer (ImageJ V1.33 ${ }^{\circledR}$, National Institutes of Health, USA). For oak, all leaves were scanned to determine whole plant leaf area, while for pine 30 needles were collected from different plant parts: basal twig (10), upper twig (10), and main stem (10). Specific leaf area (SLA) was calculated as the ratio between the leaf area and its dry mass. Leaf area of pine was estimated from SLA and the weight of needles of each plant. The roots protruding from the plug were washed and scanned (Epson Expression 1680 Pro ${ }^{\circledR}$, Epson, Japan). Roots were spread in a methacrylate tray filled with water to avoid overlap during scanning. Root length, root surface area, and root volume were measured, and root average diameter was calculated using the image analysis software, WinRHIZO Basic ${ }^{\circledR}$ (Regent Instruments Inc. Canada). Samples were oven-dried at $60{ }^{\circ} \mathrm{C}$ for $72 \mathrm{~h}$ and weighed. Total biomass, shoot biomass, total root biomass (plug + plug protruding roots), leaf biomass, and plug and stem biomass were measured; from this data, ratios of shoot/root biomass, leaf weight/plug protruding roots weight, and leaf area/plug protruding roots area were calculated. The first ratio provides insight into carbon allocation between above and below ground components, while leaf/plug protruding roots indicates the potential balance between water transpiration and water uptake capacity (Cuesta et al. 2010). Roots protruding from the plug play the most active role in uptake functions and contribute toward reestablishing water balance after planting (Grossnickle 2005). Additionally, as both uptake and transpiration flows are partly driven by leaf area, ratio on an area basis is functionally significant.

\subsection{Statistical analysis}

Chlorophyll fluorescence $\left(F_{\mathrm{v}} / F_{\mathrm{m}}\right)$ was analyzed using a repeated-measures ANOVA, with species and shelter treatments as fixed factors and measurement date as the repeated factor. Prior to this analysis, Mauchly's sphericity test was conducted to check fulfillment of necessary assumptions. The remaining variables were analyzed by factorial ANCOVA with species and shelter as fixed factors and initial height and diameter as covariables. For each analysis, when significant treatment effects were detected, statistical differences among means were identified using Fisher's protected least significant differences (LSD) test $(\alpha=0.05)$. Effects were considered significant when $P<0.05$. All statistical procedures were performed with STATGRAPHICS Plus 6.1.1 ${ }^{\circledR}$ (Manugistics Inc., USA).

\section{Results}

\subsection{Microclimatic characterization}

Mean temperature inside the shelters from 900 to 1900 hours (daytime) was similar among the four shelters, with differences of less than $1{ }^{\circ} \mathrm{C}\left(\mathrm{T} 1029.7 \pm 0.2^{\circ} \mathrm{C}\right.$ to $\mathrm{T} 4030.8 \pm 0.1{ }^{\circ} \mathrm{C}$, mean \pm standard error). Absolute maximum temperature ranged between 42 and $39{ }^{\circ} \mathrm{C}$ for the entire experimental period. Mean temperature of all shelters during daytime was $6{ }^{\circ} \mathrm{C}$ greater than the external (mesh) temperature. Vapor pressure deficit paralleled the changes of temperature: during daylight, the differences among tubes did not exceed $0.3 \mathrm{kPa}$ (T10 3.18 $\pm 0.2{ }^{\circ} \mathrm{C}$ to $\mathrm{T} 403.45 \pm 0.3^{\circ} \mathrm{C}$ ), whereas we observed differences of $1.3 \mathrm{kPa}$ for VPD averaged across shelters vs. that of mesh; maximum values showed differences of $2.5 \mathrm{kPa}$.

\subsection{Physiology}

Midday water potential $\left(\Psi_{\mathrm{M}}\right)$ was not significantly affected by tube shelter, although it was significantly affected by species $(F=21.38 ; P<0.001)$ with $\Psi_{\mathrm{M}}$ being lower in oak than in pine ( $-2.6 \pm 0.12$ vs. $-1.8 \pm 0.08 \mathrm{MPa}$, mean \pm standard error). The species $\times$ shelter interaction was not significant.

$F_{\mathrm{v}} / F_{\mathrm{m}}$ was always $>0.8$ in all measurements either at dawn or midday for both species. $F_{\mathrm{v}} / F_{\mathrm{m}}$ at dawn was only affected by measurement date $(F=13 ; P=0.001)$, although differences between dates were very small. $F_{\mathrm{v}} / F_{\mathrm{m}}$ at midday was significantly affected by tube shelter $(F=3.98 ; P=0.007)$, species $(F=4.56 ; P=0.038)$, and measurement date $(F=6.82$; $P=0.012$ ), but values were also $>0.8$ in all cases. The interaction between species and shelter was not significant.

\subsection{Growth, biomass, and morphological development}

Plant height at the end of the experiment was not affected by species, shelter, or species $\times$ shelter interaction. In contrast, root collar diameter (RCD) was affected by species $\times$ shelter interaction $(F=3.92, P=0.009)$, while in $P$. halepensis, root collar diameter decreased with shelter light transmissivity, 
with that of the darkest tube shelters (T20 and T10) being significantly smaller than that of T80 and mesh (Table 1), in $Q$. ilex, no differences in diameter among shelters appeared.

As per diameter, a significant interaction between species and shelter was detected for shoot and total biomass $(F=3.59$, $P=0.014 ; F=2.71, P=0.045$, respectively). We found no differences between treatments in $Q$. ilex, while in $P$. halepensis, mesh and T80 reached significantly higher values than in T20 and T10 (Fig. 1 and Table 1). However, the interaction was not significant for total root biomass and biomass of roots protruding from the plug. Both variables were affected by tube shelter (total root biomass: $F=8.30, P$ $<0.001$; protruding roots biomass: $F=11.30, P<0.001$, respectively), but species was only significant for total root biomass $(F=18.04, P<0.001)$. The response of the plant to the protective tube was similar in both species, with a declining trend for total and protruding roots biomass as shelters became more opaque (Fig. 1). Total root biomass of $Q$. ilex was higher than that of $P$. halepensis, following the trend prior to planting (see Section 2 for initial characterization of seedlings), but no differences in protruding roots biomass among species were found 6 months after planting (Fig. 1). Length, surface, and volume of roots protruding from the plug increased with light transmissivity (data not shown), with maximum values for the mesh and T80. In contrast, we found no difference in the average diameter of protruding roots $(0.88$ $\pm 0.12 \mathrm{~mm}$, mean \pm standard error) among shelters or species, and the interaction was not significant.

The interaction between species and tube shelter for leaf area was significant $(F=3.46, P=0.017)$, while in $P$. halepensis, leaf area decreased with shelter light transmissivity, in $Q$. ilex we found no differences between treatments (Table 1). However, SLA was not affected by tree shelter $\times$ species interaction, but the tree shelter treatment significantly affected this variable $(F=20.17, P<0.001)$. SLA maximum values were observed in T10 in both species and were 33 and $24 \%$ higher than that in T80, T40, and mesh averaged. SLA in pine was higher than in oak $(F=24.78, P<0.001)$ (Table 1).

The ratio of leaf biomass to biomass of roots protruding from the plug was affected by species $(F=210.91, P<0.001)$ and light transmissivity of the tube shelter $(F=11.30, P<$ 0.001 ). This relationship was around one third higher in pine than in oak. Nevertheless, the response to shelter type was similar in both species: a reduction up to $60 \%$ of light transmissivity did not affect this variable (Table 1 ). The species $\times$ shelter interaction was not significant on this ratio. On the other hand, the species $\times$ shelter interaction was significant for the ratio of leaf to roots protruding from the plug area $(F=$ $3.31, P=0.021$, Fig. 2): in the case of pine, we detected a trend of an increase in this ratio with decreasing light transmissivity, with a ratio that was more than three times higher for T10 than

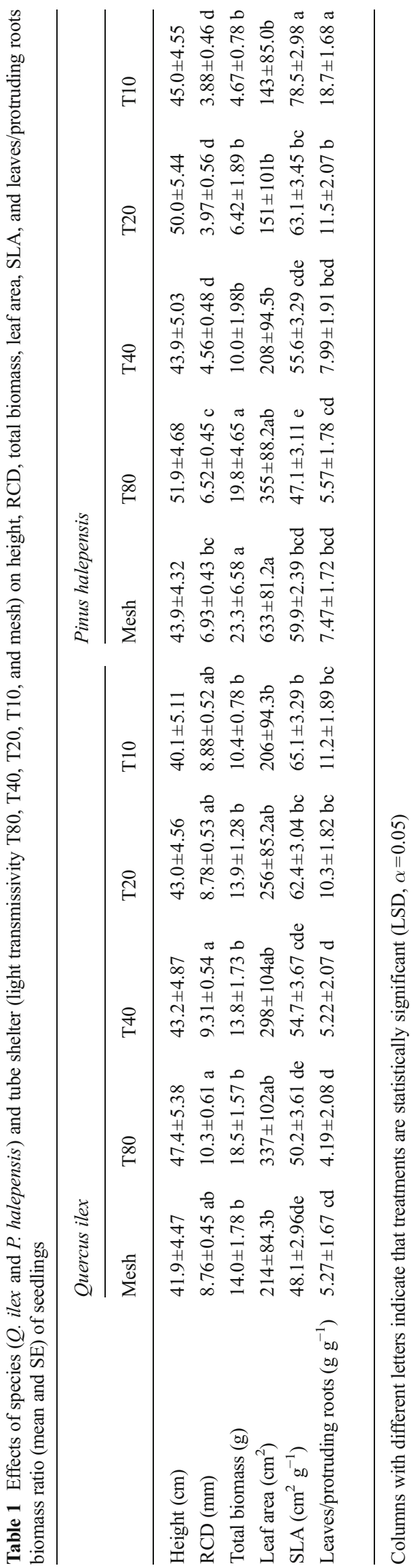




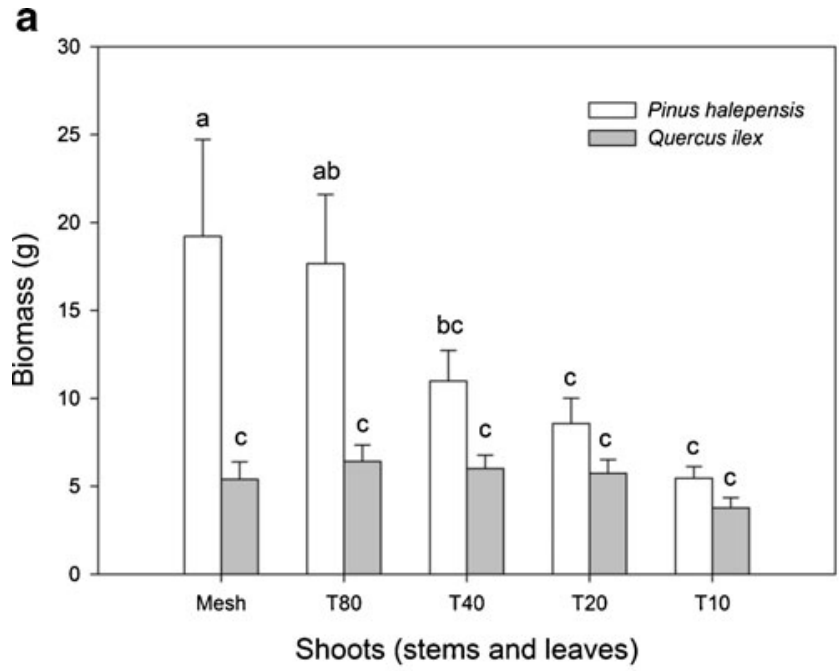

b

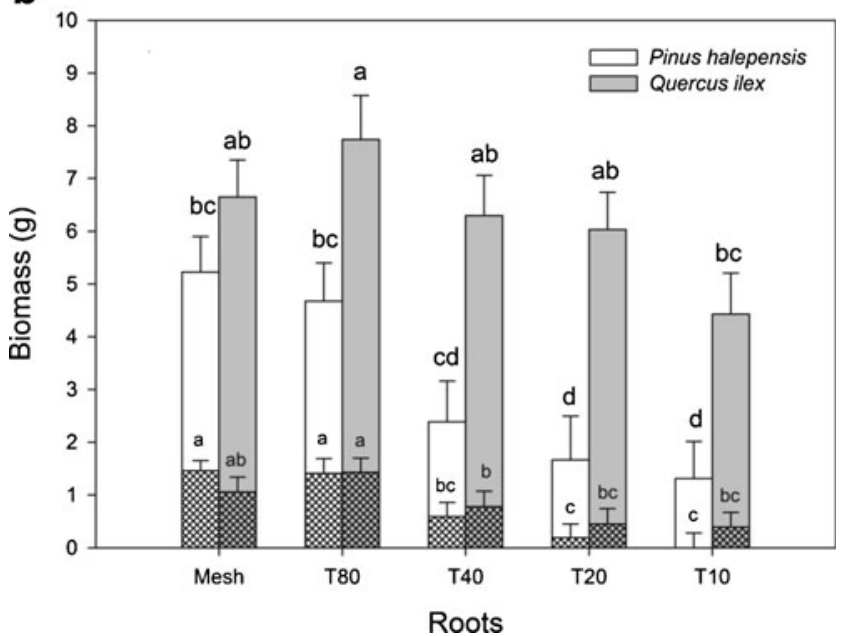

Fig. 1 Accumulated biomass (mean and SE, $n=5$ ) 6 months after planting for seedlings of $P$. halepensis and $Q$. ilex in four types of shelter transmissivity: T80, T40, T20, and T10 are tube shelters with 80, 40, 20, and $10 \%$ of light transmissivity, with mesh as a control. a Shoot (stem and leaves) biomass. $\mathbf{b}$ Total root biomass and biomass of roots protruding from the plug (grid column at the bottom). Columns with different letters indicate that means are statistically different (LSD, $\alpha=0.05$ )

T80, while in oak this trend disappeared in plants grown below $20 \%$ of light transmissivity, this treatment barely duplicating that of T80. Maximum values of this ratio were detected in T10 and T20 for pine and oak, respectively.

\section{Discussion}

\subsection{Microclimate}

Light transmissivity of tube shelters had no significant effect on air temperature. The energy budget of the internal air of the shelter reflects the differences between absorption of solar radiation and loss through the top opening (via convection)

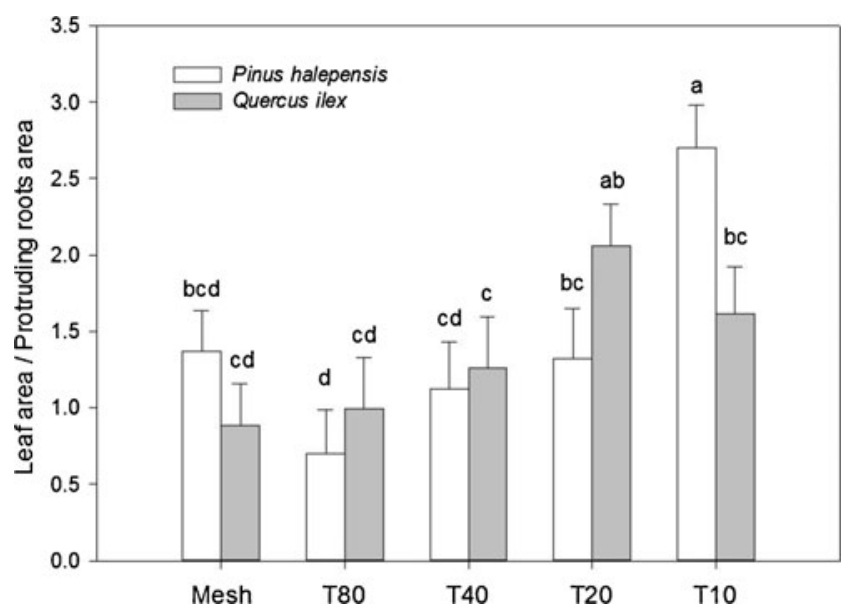

Fig. 2 Ratio of leaf area to roots protruding from the plug area (mean and SE, $n=5$ ) for each shelter: T80, T40, T20, and T10 are tube shelters with $80,40,20$, and $10 \%$ of transmissivity and mesh is the control. Columns with different letters indicate that means are statistically significant (LSD, $\alpha=0.05$ )

and the wall of the tube (Bergez and Dupraz 2009). Convective losses through the top opening are proportional to the ventilation rate (Bergez and Dupraz 2000). Lack of temperature differences in our study across a range of transmissivity may be explained by the augmented ventilation effect from the lateral holes, which, in turn, offset the differences in the increasing radiation passing the wall with higher transmissivity. Oliet et al. (2003) observed less than $3{ }^{\circ} \mathrm{C}$ and $1.2 \mathrm{kPa}$ variations between ventilated tube shelters with different light transmissivities. In our experiment, the difference among tube shelters was also less than $1.3 \mathrm{kPa}$, which may indicate that, if tube shelters are well ventilated, VPD is not dependent on the light transmissivity of tube shelters. Therefore, observed differences in morphophysiological traits of the species cannot be attributed to temperature or VPD.

\subsection{Physiology}

Our results show that, under well-watered conditions, water status of the plants was relatively unaffected by light transmissivity of the tube shelters. Other trials with Mediterranean species also reported a minimal effect of light on water potential during the wet period (Rhizopoulou et al. 1991; Pardos et al. 2005). Oliet and Jacobs (2007) found differences in midday water potential among $Q$. ilex in shelters of different light transmissivity but only in response to a shift in VPD of the air. Slight differences in evaporative demand among shelters in our study could explain similar plant water status across transmissivity levels. On the other hand, the pattern observed in our study was the same in both species despite their different water use strategies. Oak seedlings exhibit a water spending behavior (Martínez-Ferri et al. 2000), which leads to lower $\psi_{\mathrm{M}}$, but no differences were found between shelters. Pine seedlings exhibit a water saving strategy with efficient 
stomatal control (Borghetti et al. 1998) leading to high $\psi_{\mathrm{M}}$ values but still independent from light transmissivity of tube shelters. Regardless, $\Psi_{\mathrm{M}}$ values indicate low levels of water stress for both P. halepensis (Royo et al. 2001) and Q. ilex (David et al. 2007).

Predawn and midday $F_{\mathrm{v}} / F_{\mathrm{m}}$ values were around 0.8 , which is typical of non-stressed, healthy plants (Johnson et al. 1993) and indicated lack of stress to the photosynthetic machinery. The same results were found in the establishment of both of these species during the hottest summer period in a previous experiment (Puértolas et al. 2010). Additionally, in a study with the same species designed to evaluate changes in photosystem II activity due to heat exposure, Methy et al. (1997) found no significant decrease of $F_{\mathrm{v}} / F_{\mathrm{m}}$ until exposure to temperatures higher than 45 or $50{ }^{\circ} \mathrm{C}$ was maintained for more than $20 \mathrm{~min}$ for $P$. halepensis or $Q$. ilex, respectively. In our study, absolute maximum temperature did not reach $45^{\circ} \mathrm{C}$ within any shelter type, and minimal differences occurred across treatments. This could explain the high values of $F_{\mathrm{v}} /$ $F_{\mathrm{m}}$ in all species and transmissivities tested.

\subsection{Growth, biomass, and morphological development}

Tube shelters influenced plant growth under the non-limiting water availability conditions of our experiment. Root collar diameter, shoot, root, and total biomass significantly decreased with light transmissivity of tube shelters. Previous studies (Oliet et al. 2003; Navarro-Cerrillo et al. 2005) showed a decrease in stem diameter for plants growth inside tubes shelters. Results of our study also agree with Dupraz (1997a), who showed a reduction of stem diameter as light transmissivity of the shelter decreased. Experiments under shaded conditions for $Q$. ilex and other Quercus and Pinus species revealed that $80 \%$ of incident light reductions led to marked shoot and total biomass loss (Gómez-Aparicio et al. 2006; Sánchez-Gómez et al. 2006; Cardillo and Bernal 2006). In our experiment, depletion of shoot biomass and leaf area, as well as total biomass with shelter transmissivity, was more pronounced in Pinus than in Quercus. Studies carried out in Mediterranean climates showed seedlings inside tube shelters developed lower shoot biomass than growth without protection (del Campo et al. 2006). The lack of shoot biomass and leaf area response in $Q$. ilex can be attributed to the low plasticity of this species to environmental changes, especially to light availability (Sánchez-Gómez et al. 2008). Dupraz (1997a) also found a more intense growth response to shelter transmissivity in light demanding vs. shade tolerant species. On the other hand, light transmissivity of the shelter wall significantly affected SLA, associated with an increase of this variable with increasing degree of shading. The negative relationship between light levels of tube shelters and SLA has been previously observed (Close et al. 2009). The light environment is a primary determinant of this parameter, as has been observed in numerous studies with $P$. halepensis (Puértolas et al. 2009), Pinus sylvestris, Pinus pinaster, and Q. ilex (Quero et al. 2006) as well as in other tree or herbaceous species (Sánchez-Gómez et al. 2006).

The reduction of root biomass within tube shelters in temperate climates has been reported by other authors (Dupraz 1997b; Sharpe et al. 1999). Experiments carried out with $P$. halepensis and other conifers under Mediterranean climates also showed a decline in root biomass of sheltered trees (Jiménez et al. 2005; del Campo et al. 2006; Puértolas et al. 2010) with negative consequences on survival (Oliet et al. 2003). In other trials conducted with $Q$. ilex, however, tube shelters did not promote differences in root biomass (Oliet et al. 2003; Oliet and Jacobs 2007; Puértolas et al. 2010), which may be due to low plasticity of this species and because the gradient of light transmissivity evaluated was not as wide as that used in our study. Reduced post-transplant root growth impairs the ability of roots to explore soil and absorb water and nutrients, hampering establishment (Grossnickle 2005), especially when summer drought depletes water from upper layers of the profile (Villar-Salvador et al. 2012). In our study, we have clearly shown that shelter wall light transmissivity values $<40 \%$ dramatically depress growth of new roots for both species during early establishment. Furthermore, the differences in biomass of roots protruding from the plug associated with shelter type are similar to those for root length, area, and volume. Despite differences in root biomass, the absence of differences in root average diameter between types of light transmissivity suggests that this factor does not change root functional aspects, such as lignification or conductive capacity (Gómez-Aparicio et al 2006; Collet et al. 2006).

The leaves-to-protruding roots area ratio gives an idea of the potential balance between transpiring and water absorbing parts of the plant, in that low values may improve water balance and survival under water stress conditions (Lloret et al. 1999). Protruding roots may be a minor component of total root growth (Fig. 1b), but they play a crucial role in establishment success (Grossnickle 2005). Thus, seedlings growing inside of the most translucent tubes are better prepared to face harsh summer conditions. Further, according to results obtained in the ratio of leaf to root biomass and total biomass (shoot and root), plants grown inside the tubes with lower transmissivity (T20 and T10) invest less relative and absolute amounts of photosynthates toward development of new roots than plants grown in mesh and the most translucent tube (T80). These results agree with those obtained in other experiments conducted in Quercus and Pinus, where plants growing in $<20 \%$ of sunlight have higher shoot-to-root ratios than plants growing under full light (Sánchez-Gómez et al. 2006; Gómez-Aparicio et al. 2006; Cardillo and Bernal 2006). The increase of shoot in relation to roots is a characteristic reaction of young plants grown under shade (Balaguer et al. 2001), which prioritize the assignment of photosynthates to light capture (Lambers et al. 
2008). Further development of shoots at the expense of roots can be detrimental for outplanted seedlings in Mediterranean climates because during summer drought, the plants without sufficiently developed root systems in absolute or relative terms to their shoots will suffer more water stress than plants grown without protection (Villar-Salvador et al. 2012).

The studies aimed at analyzing the effect of shelters on plant performance must consider seasonal conditions during the experiment. The effect of shelters on growth compared to open planted seedlings might have been more intense if planting had been carried out in winter, as the relative increase in temperature inside tubes is higher when the solar angle is closer to perpendicular (Bergez and Dupraz 2009). However, with regard to the relative differences among shelters transmissivity, the highest growth rate in the humid season under Mediterranean climates occurs in spring when solar angle is similar to summer.

\section{Conclusions}

Under wet conditions, as per the early establishment phase of recently planted seedlings in Mediterranean climates, biomass growth inside ventilated tube shelters is mostly limited by light. In addition, seedlings grown inside of the most translucent tubes had a lower ratio of shoot/protruding roots (both in terms of biomass and area), greater root development (though fibrosity of protruding roots was unaffected), and a lower SLA. These developmental attributes suggest that seedlings grown in translucent shelters will more effectively explore new soil volume and reach a proper water balance to cope with typical Mediterranean summer drought. The lower plasticity of $Q$. ilex reduces the depression effect on new growth at similar transmissivity rates as compared to $P$. halepensis, suggesting that optimum transmissivity values will vary by species. Nevertheless, we recommend light transmissivity $\geq 40 \%$ for both species to help promote rapid and vigorous root growth immediately after planting. Future experiments should explore whether seedling established inside high-light transmitting shelters will resist detrimental circumstances under the water-limiting conditions that characterize the subsequent summer drought.

Acknowledgments We are grateful to CNCRG El Serranillo (Spain) for providing the $Q$. ilex plants. We thank The Higher School of Forestry Engineers of Politechnique University of Madrid for experimental site facilities. We also thank F. Teso, F. Lucas, T. Sánchez, and R. Garrido for technical support during the experiment.

Funding This study was supported by TRACE-Project PET2008_0325 (Spanish Ministry of Science and Innovation) and co-financed by Respol Química S.A. (Spain). Polytechnic University of Madrid supported the visiting Professorship of D.F. Jacobs during the course of the study.

\section{References}

Alía Miranda R, García del Barrio JM, Iglesias Sauce S, Mancha Núñez JA, de Miguel y del Ángel J, Nicolás Peragón JL, Pérez Martín F, Sánchez de Ron D (2009) Regiones de procedencia de especies forestales españolas. Organismo Autónomo Parques Nacionales, Madrid

Balaguer L, Martínez-Ferri E, Valladares F, Pérez-Corona ME, Baquedano FJ, Castillo FJ, Manrique E (2001) Population divergence in the plasticity of the response of Quercus coccifera to the light environment. Funct Ecol 15:124-135

Bellot J, Ortiz de Urbina JM, Bonet A, Sánchez JR (2002) The effect of tree shelters on the growth of Quercus coccifera $\mathrm{L}$. seedlings in a semiarid environment. Forestry $75: 89-106$

Bergez JE, Dupraz C (2000) Effect of ventilation on growth of Prunus avium L. seedlings in treeshelters. Agr Forest Meteorol 104:199214

Bergez JE, Dupraz ZC (2009) Radiation and thermal microclimate in tree shelter. Agric Forest Meteorol 149:179-186

Borghetti M, Cinnirella S, Magnani F, Saracino A (1998) Impact of longterm drought on xylem embolism and growth in Pinus halepensis Mill. Trees 12:187-195

Cardillo E, Bernal CJ (2006) Morphological response and growth of cork oak (Quercus suber L.) seedlings at different shade levels. Forest Ecol Manag 222:296-301

Close DC, Ruthrof KX, Turner S, Rokich DP, Dixon KW (2009) Ecophysiology of species with distinct leaf morphologies: effects of plastic and shadecloth tree guards. Rest Ecol 17:33-41

Collet C, Lof M, Pages L (2006) Root system development of oak seedlings analysed using an architectural model. Effects of competition with grass. Plant Soil 279:367-383

Cuesta B, Vega J, Villar-Salvador P, Rey Benayas JM (2010) Root growth dynamics of Aleppo pine (Pinus halepensis Mill) seedlings in relation to shoot elongation, plant size and tissue nitrogen concentration. Trees 24:899-908

David TS, Henriques MO, Kurz-Besson C, Nunes J, Valente F, Vaz M, Pereira JS, Siegwolf R, Chaves MM, Gazarini LC, David JS (2007) Water use strategies in two co-occurring Mediterranean evergreen oaks: surviving the summer drought. Tree Physiol 27:793-803

del Campo AD, Navarro RM, Aguilella A, González E (2006) Effect of tree shelter design on water condensation and run-off and its potential benefit for reforestation establishment in semiarid climates. Forest Ecol Manag 235:107-115

Dupraz C (1997a) Les protections de plants à effet de serre. Première partie: ce qu'en pensent les arbres. Revue Forestiere Francaise 49: $417-432$

Dupraz C (1997b) Les protections de plants à effet de serre. Deuxième partie: amélioration de leur efficacité par aération optimisée et luminosité accrue. Revue Forestiere Francaise 49:519-530

Dupraz C, Bergez JE (1999) Carbon dioxide limitation of the photosynthesis of Prunus avium L. seedlings inside an unventilated tree shelter. Forest Ecol Manag 119:89-97

Gómez-Aparicio L, Valladares F, Zamora R (2006) Differential light responses of Mediterranean tree saplings: linking ecophysiology with regeneration niche in four co-occurring species. Tree Physiol 26:947-958

Grossnickle SC (2005) Importance of root growth in overcoming planting stress. New Forest 30:273-294

Jiménez MN, Navarro FB, Ripoll MA, Bocio I, De Simón E (2005) Effect of shelter tubes on establishment and growth of Juniperus thurifera L. (Cupressaceae) seedlings in Mediterranean semi-arid environment. Ann Forest Sci 62:717-725

Johnson GN, Young AJ, Scholes JD, Horton P (1993) The dissipation of excess excitation energy in British plant species. Plant Cell Environ 16:673-679 
Lambers H, Chapin FS, Pons TL (2008) Plant physiological ecology, 2nd edn. Springer, New York

Lloret F, Casanovas C, Peñuelas J (1999) Seedling survival of Mediterranean shrubland species in relation to root:shoot ratio, seed size and water and nitrogen use. Funct Ecol 13:210-216

MAPA (2006) Forestación de tierras agrícolas. Análisis de su evolución y contribución a la fijación del carbono y al uso racional de la tierra. Ministerio de Agricultura, Pesca y Alimentación, Madrid

Martínez-Ferri E, Balaguer L, Valladares F, Chico JM, Manrique E (2000) Energy dissipation in drought-avoiding and drought-tolerant tree species at midday during the Mediterranean summer. Tree Physiol 20:131-138

Methy M, Gillon D, Houssard C (1997) Temperature-induced changes of photosystem II activity in Quercus ilex and Pinus halepensis. Can J For Res 27:31-38

Navarro-Cerrillo RM, Fragueiro B, Ceaceros C, del Campo A, de Prado R (2005) Establishment of Quercus ilex L. subsp. ballota [Desf.] Samp. using different weed control strategies in southern Spain. Ecol Eng 25:332-342

Ninemets U, Valladares F (2006) Tolerance to shade, drought, and waterlogging of temperate Northern hemisphere trees and shrubs. Ecological Monographs 76:521-547

Oliet JA, Jacobs DF (2007) Microclimatic conditions and plant morphophysiological development within a tree shelter environment during establishment of Quercus ilex seedlings. Agr Forest Meteorol 144: $58-72$

Oliet JA, Jacobs DF (2012) Restoring forests: advances in techniques and theory. New For 43:535-541

Oliet JA, Navarro RM, Contreras O (2003) Evaluación de la aplicación de mejoradores y tubos en repoblaciones forestales. Consejería de Medio Ambiente de la Junta de, Andalucía, Sevilla

Oliet JA, Planelles R, Artero F, Jacobs DF (2005) Nursery fertilization and tree shelters affect long-term field response of Acacia salicina Lindl. planted in Mediterranean semiarid conditions. Forest Ecol Manag 215:339-351

Padilla FM, Miranda JD, Ortega R, Hervás M, Sánchez J, Pugnaire FI (2011) Does shelter enhance early seedling survival in dry environments? A test with eight Mediterranean species. Appl Veg Sci 14:31-39

Palacios G, Navarro Cerrillo RM, Del Campo A, Toral M (2009) Site preparation, stock quality and planning date effect on early establishment of holm oak (Quercus ilex L.) seedlings. Ecol Eng 35:3846

Pardos M, Jiménez M, Aranda I, Puértolas J, Pardos JA (2005) Water relations of cork oak (Quercus suber L.) seedlings in response to shading and moderate drought. Ann For Sci 62:377-384

Pausas JG, Bladé C, Valdecantos A, Seva JP, Fuentes D, Alloza JA, Vilagrosa A, Bautista S, Cortina J, Vallejo R (2004) Pines and oaks in the restoration of Mediterranean landscapes of Spain: new perspectives for an old practice - a review. Plant Ecol 171:209-220

Pemán J, Peguero-Pina JJ, Valladares F, Gil-Pelegrín E (2010) Evaluation of unventilated treeshelters in the context of Mediterranean climate: insights from a study on Quercus faginea seedlings assessed with a 3D architectural plant model. Ecol Eng 36:517-526

Puértolas J, Benito LF, Peñuelas JL (2009) Effects of nursery shading on seedling quality and post-planting performance in two Mediterranean species with contrasting shade tolerance. New Forests 38:295-308

Puértolas J, Oliet JA, Jacobs DF, Benito LF, Peñuelas JL (2010) Is light the key factor for success of tube shelters in forest restoration plantings under Mediterranean climates? Forest Ecol Manag 260: 610-617

Quero JL, Villar R, Marañón T, Zamora R (2006) Interactions of drought and shade effects on seedlings of four Quercus species: physiological and structural leaf responses. New Phytol 170:819-834

Rhizopoulou S, Meletiou-Christou MS, Diamantoglou S (1991) Water relations for sun and shade leaves of four Mediterranean evergreen sclerophylls. J Exp Bot 42:627-635

Royo A, Gil L, Pardos JA (2001) Effect of water stress conditioning on morphology, physiology and field performance of Pinus halepensis Mill. seedlings. New Forests 21:127-140

Sánchez-Gómez D, Valladares F, Zavala MA (2006) Functional traits and plasticity in response to light in seedlings of four Iberian forest tree species. Tree Physiol 26:1425-1433

Sánchez-Gómez D, Zavala MA, Valladares F (2008) Functional traits and plasticity linked to seedlings performance under shade and drought in Mediterranean woody species. Ann For Sci 65:311-321

Savill P, Evans J, Auclair D, Falck J (1997) Plantation silviculture in Europe. Oxford University Press, UK

Sharew H, Hairston-Strang A (2005) A comparison of seedling growth and light transmission among tree shelter. North J Appl For 22:102110

Sharpe WE, Swistock BR, Mecum KE, Demchik MC (1999) Greenhouse and field growth of northern red oak seedlings inside different types of tree shelters. Journal of Arboriculture 25:249-257

Valladares F, Aranda I, Sánchez-Gómez D (2004) La luz como factor ecológico y evolutivo para las plantas y su interacción con el agua. In: Valladares F (ed) Ecología del bosque mediterráneo en un mundo cambiante. Ministerio de Medio Ambiente, Madrid, pp 335-369

Villar-Salvador P, Puértolas J, Cuesta B, Uscola M, Heredia N, Peñuelas JL, Rey-Benayas JM (2012) A physiological conceptual model for explaining the superior out-planting performance of large and rich nutrient seedlings in Mediterranean environments. New Forests 43: $755-770$

Whitcomb C (2005) A Contained Career. American Nurseryman 201:16-21 